\title{
RANCANG BANGUN SISTEM INFORMASI AKADEMIK BERBASIS WEB PADA INSTITUT TRAINING CENTER PEMUDA CENDEKIA BANGSA
}

\author{
Arif Nurrochman ${ }^{1}$, Syepry Maulana ${ }^{2}$ \\ ${ }^{1,2}$ Program Studi Teknik Informatika, Fakultas Teknik, Universitas Muhammadiyah Tangerang \\ J1. Perintis Kemerdekaan 1/33 Cikokol Kota Tangerang \\ Co Responden Email: arifnurrochman10@gmail.com
}

Article history

Received Nov 06, 2020

Revised Jan 03, 2021

Accepted Jan 30, 2021

Available online Feb 27, 2021

Keywords

Systems, Information, Academic, Web.

Riwayat

Diterima 06 Nov 2020

Revisi 03 Jan 2021

Disetujui 30 Jan 2021

Terbit 27 Feb 2021

Kata Kunci

Sistem, Informasi, Akademik, Web.
Abstract

The development of information technology, which is increasingly fast and fast, becomes a formidable challenge for a company or educational institution, both public and private. Every education sector is expected to be able to utilize information technology as a support for operational activities in generating information. Academic information systems at the National Youth Scholarship Training Center are still done manually, with a data collection system that is now felt there are still many shortcomings that occur, because the existing system still uses sheets of paper and archives so that the data is very likely to be lost or damaged. The system design in the form of making a web-based academic information system at the Institute of Youth Education Center Training Center is a system that provides information management information regularly and effectively, and can print the results of data recap, academic data at the National Institute of Youth Scholarship Training Center is called master academic data from employee data, mentor data, student data, program data, data studies, value data, material data, and asset data so as to help speed and quality in the delivery of information. So that it can be expected to be implemented in a product that will correct any deficiencies that exist in the old system. Web-based academic information system uses Bootstrap Framework with PHP programming language with MySQL database.

\section{Abstrak}

Perkembangan teknologi informasi yang semakin pesat dan pesat menjadi tantangan yang berat bagi suatu perusahaan atau lembaga pendidikan baik negeri maupun swasta. Setiap bidang pendidikan diharapkan mampu memanfaatkan teknologi informasi sebagai penunjang kegiatan operasional dalam menghasilkan informasi. Sistem informasi akademik di Pusdiklat Beasiswa Remaja Nasional masih dilakukan secara manual,. Perancangan sistem berupa pembuatan sistem informasi akademik berbasis web pada Balai Diklat Balai Diklat Pemuda merupakan suatu sistem yang menyediakan informasi pengelolaan informasi secara teratur dan efektif, serta dapat mencetak hasil rekap data akademik di tingkat Nasional. Lembaga Pusat Diklat Beasiswa Pemuda disebut sebagai data master akademik dari data kepegawaian, data pembimbing, data mahasiswa, data program, data studi, data nilai, data materi, dan data aset sehingga dapat membantu kecepatan dan kualitas dalam penyampaian informasi. Sehingga diharapkan dapat diimplementasikan pada suatu produk yang akan memperbaiki segala kekurangan yang ada pada sistem yang lama. Sistem informasi akademik berbasis web menggunakan Framework Bootstrap dengan bahasa pemrograman PHP dengan database MySQL. 


\section{PENDAHULUAN}

Institut Training Center Pemuda Cendekia Bangsa salah satu Lembaga pendidikan yang belum memiliki sistem informasi ini, sistem informasi yang dibangun masih manual yaitu pencatatan dan penilaian masih menggunakan form berbentuk kertas sehingga dalam pengarsipan masih menggunakan bindex dan disimpan di lemari terkadang dalam proses pengecekan kembali data yang telah diarsip terjadi keterlambatan yang mengakibatkan suatu hambatan bagi pengajar dan siswa. Oleh karena itu, penulis memilih Institut Training Center Pemuda Cendekia Bangsa sebagai objek penelitian, ini dirasa sangat memerlukan sistem informasi guna memberikan kemudahan baik kepada pengajar dalam menginformasikan pelaporan kegiatan akademik siswa. Dengan begitu proses pelaporan data nilai, absensi siswa dapat diinformasikan dengan cepat dan dapat melihat jadwal mengajar,dan biodata guru.

Dalam hal ini penulis merumuskan permasalahan yaitu sebagai berikut:

- Bagaimana merancang sistem informasi akademik berbasis web Institut Training Center Pemuda Cendekia Bangsa yang pengolahannya menggunakan dengan Sublime Text, PHP, dan MYSQL, serta Framework Bootstrap ?

- Bagaimana mengelola master data akademik untuk mempermudah akademik dalam melakukan manipulasi (penambahan, menghapus, mengedit serta pencarian) terhadap data yang ada?

Di dalam penelitian ini terdapat dua jenis tujuan, yaitu yaitu tujuan umum dan tujuan khusus. Tujuan umum penelitian ini adalah untuk menghasilkan sistem informasi akademik berbasis web. Sedangkan tujuan khusus dari penelitian ini adalah untuk menghasilkan :

a. Membuat sistem informasi akademik yangmampu memberikan kemudahan bagi pengguna untuk mengelola data akademik di Institut Training Center Pemuda Cendekia Bangsa.

b. Mengelola master data akademik untuk mempermudah akademik dalam melakukan manipulasi ( penambahan, menghapus, mengedit serta pencarian ) terhadap data yang ada.

c. Merancang sistem informasi akademik berbasis web Institut Training Center Pemuda Cendekia Bangsa yang pengolahannya menggunakan dengan Sublime Text, PHP, dan MYSQL, serta Framework Bootstrap.

\section{LANDASAN TEORI}

Menurut Pressman (2009) "perancangan atau rancang merupakan serangkaian prosedur untuk menterjemahkan hasil analisa dan sebuah sistem ke dalam bahasa pemrograman untuk mendeskripsikan dengan detail bagaimana komponen-komponen sistem di implementasikan."

Menurut Pressman (2009) pengertian "pembangunan atau bangun sistem adalah kegiatan menciptakan sistem baru maupun mengganti atau memperbaiki sistem yang telah ada secara keseluruhan."

Menurut Susanto (2013) "sistem informasi adalah kumpulan dari sub-sub sistem baik fisik maupun non fisik yang saling berhubungan satu sama lain dan bekerja sama secara harmonis untuk mencapai satu tujuan yaitu mengolah data menjadi informasi yang berguna."

Pengertian akademik menurut Subhansyah (2011) "akademik adalah seluruh Lembaga pendidik formal baik pendidikan anak usia dini, Pendidikan dasar, pendidikan menengah, Pendidikan kejuruan maupun perguruan tinggi yang menyelenggarakan Pendidikan vokasi dalam suatu cabang atau sebagian cabang ilmu pengetahuan, teknologi, dan atau seni tertentu."

\section{Teori Sistem Informasi Akademik}

Pengertian Sistem Informasi Akademik menurut Jamilah (2011) merupakan "sistem yang mengolah data dan melakukan proses kegiatan akademik yang melibatkan antara siswa, guru, administrasi akademik, penilaian dan data atribut lainnya."

\section{Perancangan Sistem Informasi}

Langkah awal yang dilakukan penyusun dalam membangun sistem informasi adalah dengan menentukan model sistem informasi yang akan dipakai. Dalam hal ini peneliti menentukan atau memilih 
model sistem informasi tersebut dengan salah satu model sistemnya menggunakan model sistem waterfall. Model sistem waterfall seperti gambar di bawah ini :

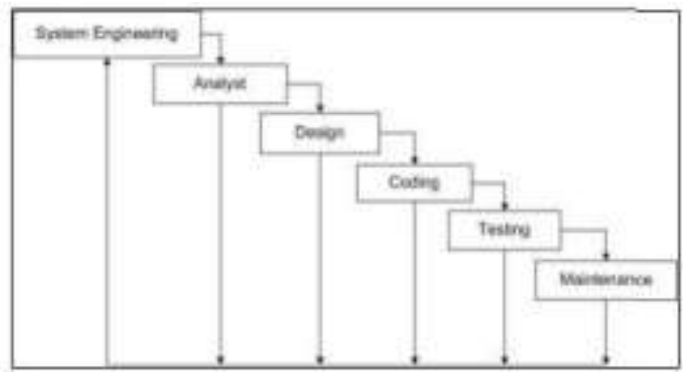

Gambar 2.2. Model Sistem

Waterfall ( Ian Sommerville, 2011)

Model sistem seperti ini menuntut cara yang teratur dari suatu rangkaian yang mendekati perkembangan software (perangkat lunak). Perkembangan software ini dimulai dengan suatu tingkatan kemajuankemajuan melalui analisis (analyst), perancangan (design), pengkodean (coding), pengujian (testing) dan pemeliharaan (maintenance).

\section{METODOLOGI PENELITIAN}

\section{Metode Pengumpulan Data}

Dalam penyusunan skripsi ini, diperlukan data-data serta informasi yang relatif lengkap sebagai bahan yang dapat mendukung kebenaran materi uraian dan pembahasan. Oleh karena itu, sebelum penyusunan skripsi ini dilakukan, maka dilakukan riset atau penelitian terlebih dahulu untuk menjaring data serta informasi yang terkait.
Teknik pengumpulan data yang dilakukan adalah sebagai berikut :

Pada metode ini untuk menelaah masalah secara mendalam yang berkaitan dengan tugas akhir, maka laporan ini disusun dengan melakukan studi pustaka, yaitu dengan mengumpulkan data-data teoritis dan mempelajari buku-buku atau literature dengan maksud untuk mendapatkan teori- teori dan bahan-bahan yang berkaitan dengan masalah yang dibahas. Adapun teori-teori yang menjadi acuan dalam tugas akhir ini adalah : A. Tulisan dan artikel dari internet, serta buku-buku lain untuk selengkapnya sudah tercantum pada bagian daftar pustaka.

Beberapa literature yang digunakan yang bersumber dari skripsi dan jurnal, dimana sumber dari skripsi dan jurnal ini tercantum didalam daftar pustaka.

Observasi, Pada metode pengamatan (observasi) ini dilakukan peninjauan dan penelitian langsung di lapangan untuk memperoleh dan mengumpulkan data yang dibutuhkan. Pengamatan ini dilakukan pada Institute Training Center Pemuda Cendekia Bangsa. Dari hasil pengamatan ini, proses pemberkasan akademik di Lembaga masih bersifat manual, seperti mentor menilai mahasiswa masih menggunakan form dan arsip tentang data siswa,data karyawan dan data mentor serta yang lain-lain masih bersifat form dan diarsipkan di bindex , hal kekurangan ini akan diatasi dengan membuat sistem informasi yang nantinya akan memuaskan para karyawan Lembaga dan mahasiswa di Institute Training Center Pemuda Cendekia Bangsa. Observasi dilakukan dengan mengumpulkan data dan informasi yang 


\section{Wawancara}

Wawancara dilakukan dengan cara mewawancarai secara langsung pihakpihak terkait, yang berguna untuk mendapatkan informasi maupun data- data yang dibutuhkan untuk perancangan dan pembangunan sistem yang akan dibuat, yaitu wawancara terhadap pihak Institute Training Center Pemuda Cendekia Bangsa, dengan melakukan wawancara kepada Bapak Ahmad Zaki, ST sebagai direktur.

\section{Metodologi Analisa dan Perancangan Metode Analisa Sistem}

Pada tahap analisa dilakukan terhadap sistem manual akademik yang sudah diterapkan ITC PCB. Hal ini dilakukan untuk mengetahui apakah sistem tersebut sudah dapat memenuhi kebutuhan manajemen dalam kaitannya dengan pengambilan keputusan. Analisa dilakukan untuk mengetahui kebutuhan sistem informasi Akademik pada ITC PCB dengan meneliti dari mana data berasal, bagaimana aliran data menuju sistem, bagaimana operasi sistem yang ada dan hasil akhirnya.

\section{Metode Perancangan Sistem}

Berdasarkan analisa dari uraian diatas maka dapat dirancang sebuah model pengembangan sistem, dimana model pengembangan ini terdari dari input, proses serta output yang diperlukan dalam membangun sistem tersebut. Sistem ini dirancang untuk menampung data yang telah diolah dari web server dan terbagi menjadi dua user yaitu admin, direktur, mentor dan siswa.

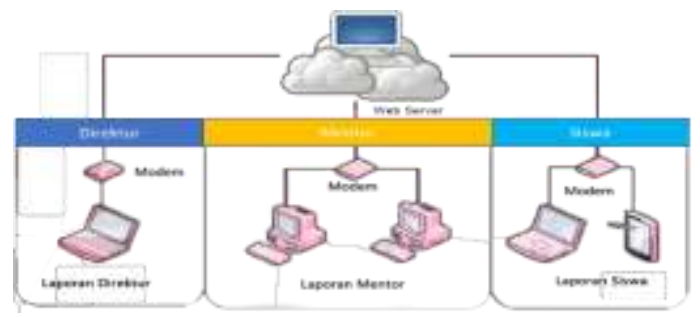

Gambar 3.1 Arsitektur Sistem SIAKAD
Laporan tersebut berdasarkan data yang telah diolah dari web server sehingga terbagi dalam 4 pengguna yaitu Admin, Direktur, Mentor, dan Siswa. Apabila di rinci lebih lanjut, maka laporan yang dihasilkan dapat dilihat pada blok diagram pada Gambar 3.2.

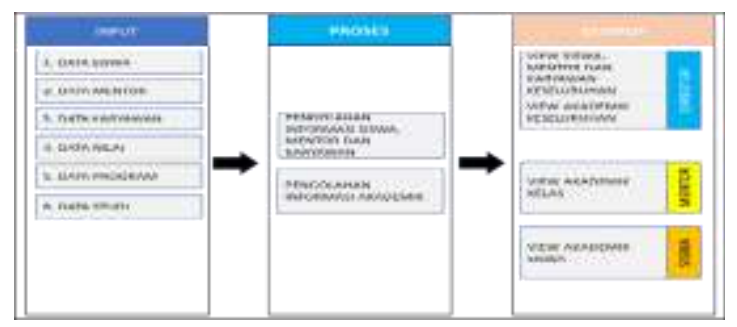

\section{Gambar 3.2 Diagram Input Proses Output Sistem Informasi Akademik ITC PCB}

Gambar 3.2 menjelaskan bahwa terdapat dua proses utama yaitu pengolahan informasi siswa, mentor, serta karyawan dan pengolahan informasi akademik

Pengguna sistem memiliki kebutuhan informasi yang berbeda.

Direkturmembutuhkan laporan siswa,mentor dan

karyawan, serta akademik. Mentor membutuhkan informasi menyangkut kegiatan akademik siswa yang diajar. Sedangkan siswa membutuhkan informasi tentang kegiatan akademik satu siswa. Untuk dapat melihat lebih detail tetang laporan yang dihasilkan maka akan dijelaskan pada Gambar 3.3

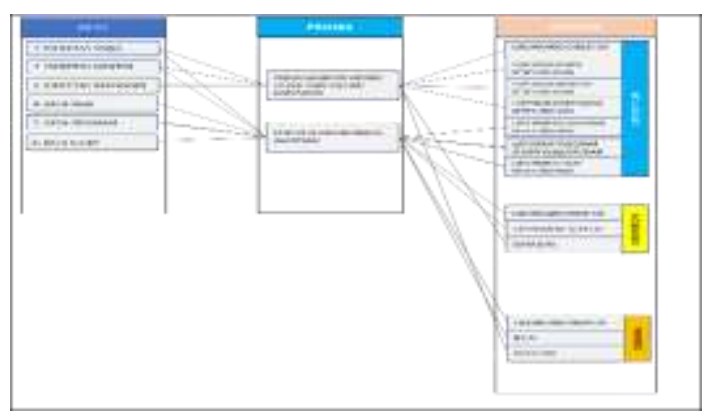




\section{Gambar 3.3 Alur Pengolahan Informasi Sistem Informasi Akademik ITC PCB}

Gambar 3.3 menjelaskan tentang bagaimana data dimasukan ke dalam 2 proses yaitu proses pengolahan informasi siswa,mentor serta karyawan dan pengolahan informasi akademik sehingga menghasilkan laporan masing masing user. laporan yang ditampilkan pada Gambar 3.3 adalah laporan yang bersifat lebih detil dibandingkan dengan Gambar 3.2.

\subsection{Metode Pengembangan Sistem}

\section{a. Konsep Metode \\ Pengembangan Sistem}

Model air terjun (waterfall) Biasa juga disebut siklus hidup perangkat lunak. Mengambil kegiatan dasar seperti spesifikasi, pengembangan, validasi, dan evolusi dan merepresentasikannya sebagai fase-fase proses yang berbeda seperti spesifikasi persyaratan, perancangan perangkat lunak, implementasi, pengujian dan seterusnya.

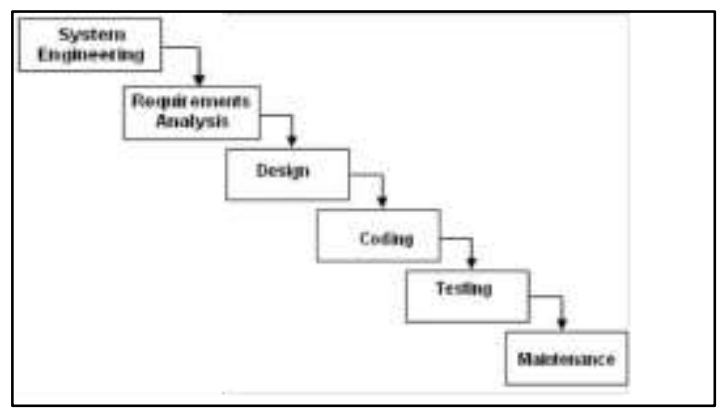

Gambar 3.4 Model Waterfall ( Sumber: Jogiyanto H.M (2010))
Keterangan Menurut gambar diatas alur dari Model Waterfall sebagai berikut:

- Rekayasa perangkat lunak (system enginerring),melakukan pengumpulan data dan penetapan kebutuhan semua elemen system

- Requirements analysis melakukan analisis terhadap permasalahan yang dihadapi dan menetapkan kebutuhan perangkat lunak, fungsi performsi dan interfacing.

- Design, menetapkan domain informasi untuk perangkat lunak,fungi dan interfacing.

- Coding (implementasi), pengkodean yang mengimplementasikan hasil desain ke dalam kode atau bahasa yang dimengerti oleh mesin komputer dengan menggunakan bahasa pemprograman tertentu.

- Testing (pengujian), kegiatan untuk melakukan pengetesan program yang sudah dibuat apakah udah benar atau belum di uji dengan cara manual.jika testing sudah benar maka program boleh digunakan

- Maintenance (perawatan), menangani perangkat lunak yang sudah selesai supaya dapat 
berjalan lancar dan terhindar dari gangguangangguan yang dapat menyebabkan kerusakan.

\section{Metode Pengujian Sistem \\ Metode Black Box Testing}

Untuk dapat

mengetahui apakah Sistem Informasi Akademik ITC PCB telah sesuai dengan kebutuhan, maka perlu dilakukan pengujian dengan pendekatan metode Black Box Testing. Black Box Testing adalah metode yang menguji setiap unit program serta memastikan apakah telah sesuai dengan spesifikasi sistem. Secara umum, pengujian dilakukan pada proses login, pengelolaan data master dan pelaporan pada masing masing user. Hal - hal yang diujikan ada pada Tabel 3.1

\section{Tabel 3.1 Rencana Pengujian Sistem \\ B \\ Informasi Akademik ITC PC}

\begin{tabular}{|l|l|}
$\begin{array}{l}\text { Requirement } \\
\text { yang diuji }\end{array}$ & \multicolumn{1}{|c|}{ Fungsi yang diuji } \\
Login & Melakukan Login \\
\hline Halaman & Melakukan operasi CRUD \\
Menter Data & (Create, Read, Update, \\
& $\begin{array}{l}\text { Delete }) \text { pada proses input } \\
\text { data master mentor }\end{array}$ \\
\hline
\end{tabular}

\begin{tabular}{|l|l|}
\hline Halaman Master & $\begin{array}{l}\text { Melakukan operasi } \\
\text { CRUD (Create, Read, } \\
\text { Update, Delete }) \text { pada }\end{array}$ \\
proses input data \\
Dataman Program \\
master karvawan
\end{tabular}




\begin{tabular}{|c|c|}
\hline & $\begin{array}{l}\text { Delete) pada proses input } \\
\text { data master nilai siswa }\end{array}$ \\
\hline $\begin{array}{l}\text { Halaman } \\
\text { Master Data } \\
\text { Prestasi }\end{array}$ & $\begin{array}{l}\text { Melakukan operasi CRUD } \\
\text { (Create, Read, Update, } \\
\text { Delete) pada proses input } \\
\text { data master nilai prestasi }\end{array}$ \\
\hline
\end{tabular}

\section{HASIL DAN PEMBAHASAN}

\section{Tampilan Login}

Halaman ini merupakan halaman login administrator untuk masuk ke dalam sistem dengan memasukkan username dan password yang dimasukkan valid. Berikut tampilan halaman login administrator :

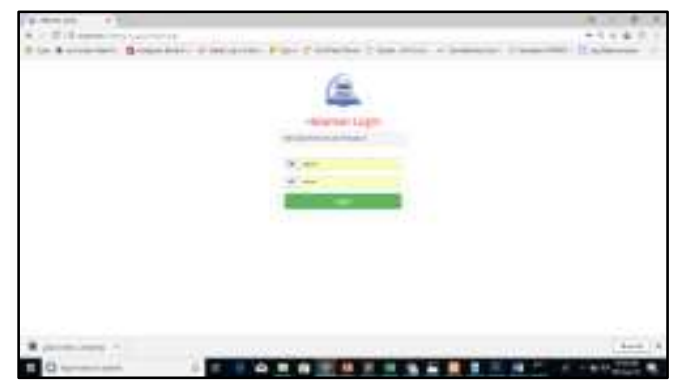

\section{Gambar 4.1 Tampilan Halaman login}

\section{Tampilan Menu Utama}

Halaman ini merupakan halaman index admin. Pada halaman ini ada beberapa menu antara lain yaitu : master data mentor, master data karyawan, master data program, master data study, master data siswa, master data nilai, manajemen user. Berikut tampilan halaman menu utama :

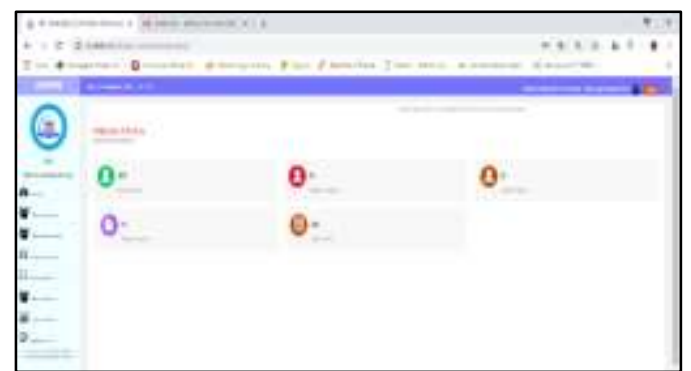

Gambar 4.2 Tampilan Halaman Menu Utama

\section{Tampilan Menu Tambah Data Master Data}

Halaman ini merupakan halaman untuk menambah data, setelah selesai memasukkan data maka data akan tersimpan pada database yang telah dibuat. Berikut adalah tampilan tambah data:

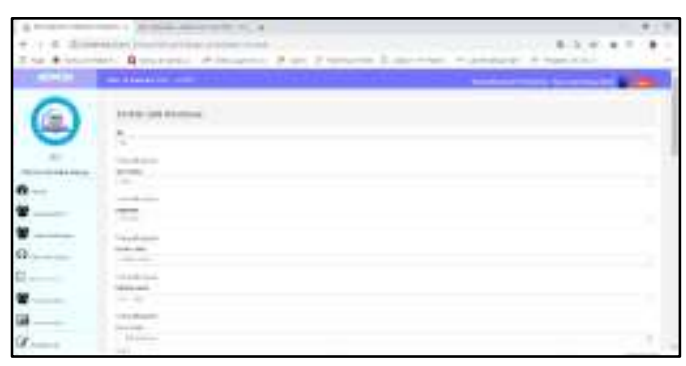

Gambar 4.3 Tampilan Halaman Tambah Data

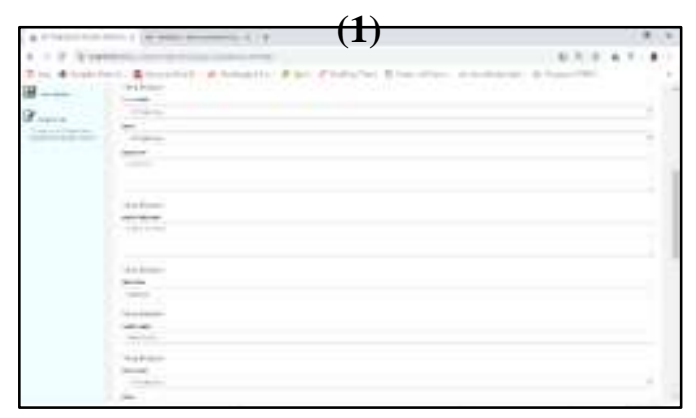

Gambar 4.4 Tampilan Halaman Tambah Data

(2) 


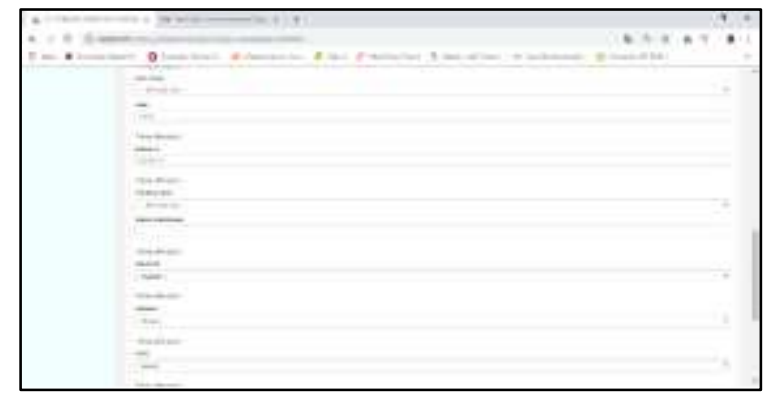

Gambar 4.5 Tampilan Halaman Tambah Data (3)

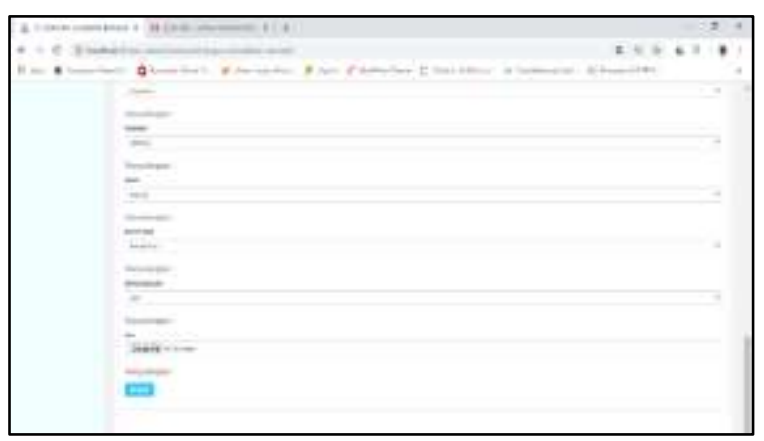

Gambar 4.6 Tampilan Halaman Tambah Data (4)

\section{Tampilan Menu Edit Data Master Data}

Halaman ini merupakan halaman untuk mengedit data jika ada data yang salah atau untuk memperbaharui data, setelah selesai memasukkan data maka data akan tersimpan pada database yang telah dibuat. Berikut adalah tampilan tambah data :

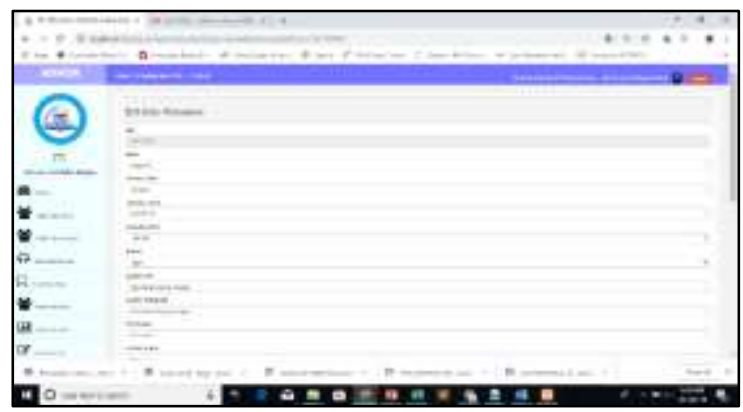

Gambar 4.7 Tampilan Halaman Edit Data (1)

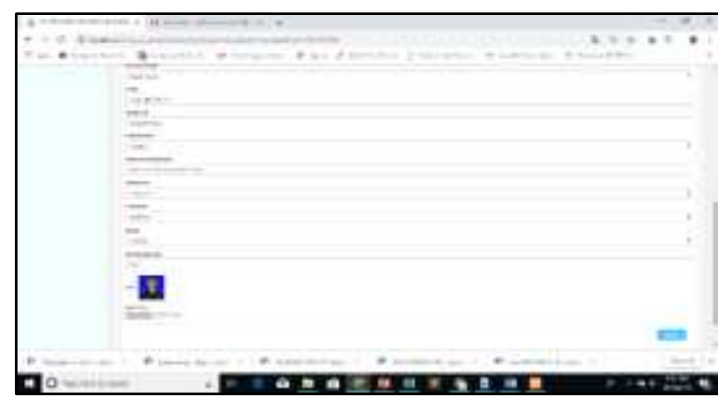

\section{Gambar 4.8 Tampilan Halaman Edit Data (2)}

\section{Tampilan Menu Hapus Data Master data}

Halaman ini merupakan halaman untuk mengedit data jika ada data yang salah atau untuk memperbaharui data, setelah selesai maka data akan tarhapus pada database. Berikut adalah tampilan tambah data :

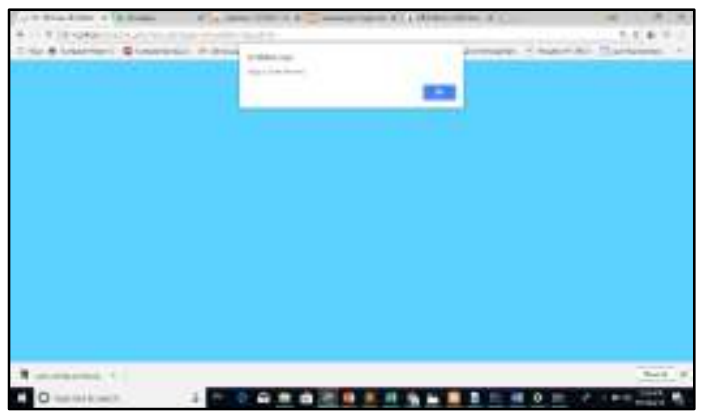

Gambar 4.9 Tampilan Halaman Hapus Data

\section{Tampilan Menu Detail Data Master Data}

Halaman ini merupakan halaman untuk melihat detail data. Berikut adalah tampilan detail data :

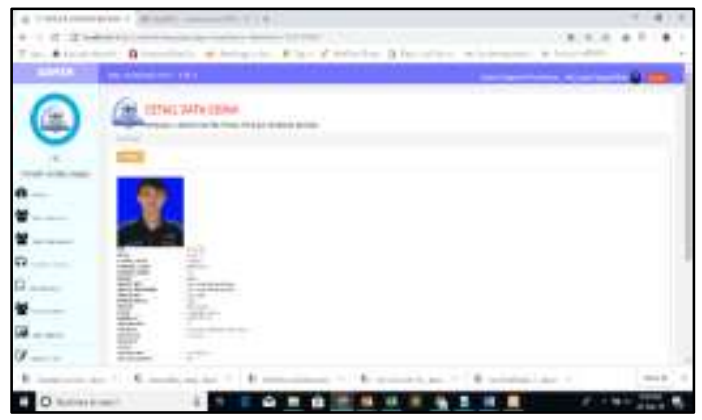

Gambar 4.10 Tampilan Halaman Detail Data 


\section{Tampilan Menu Cetak Data Master Data}

Halaman ini merupakan halaman untuk mencetak data. Berikut adalah tampilan detail data :

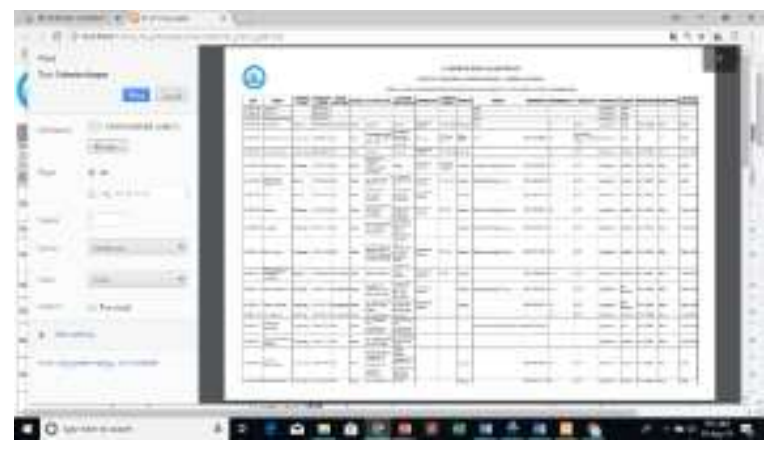

Gambar 4.11 Tampilan Halaman Cetak Data

\section{KESIMPULAN}

Dari hasil pembahasan, maka menghasilkan beberapa simpulan sebagai berikut :

- Dengan merancang dan mengimplementasikan sebuah sistem informasi dengan berbasis web maka mempermudah direktur, admin, mentor, dan mahasiswa dalam mengontrol dan mengelola data akademik.

- Dengan adanya sistem informasi akademik, admin dapat mengelola data master akademik hanya dengan mengklik beberapa tombol navigasi yang ada pada masing-masing form dalam tampilan web.

- Sistem informasi akademik yang dirancang menghasilkan sistem akademik yang lebih efisien dan efektif dalam pengelolaan data master akademik, pembuatan laporan serta dapat mengatasi masalah human error.

\section{REFERENSI}

A.S., Rosa dan Shalahuddin, M. 2013. Rekayasa Perangkat Lunak Terstruktur Dan Berorientasi Objek. Bandung: Informatika.

Abdul Kadir. 2014. Pengenalan Sistem Informasi Edisi Revisi. Andi.Yogyakarta.

Al-Bahra Bin Ladjamudin. 2013. Analisis Dan Desain Sistem Informasi. Graha Ilmu. Yogyakarta.
Ana Hadiana. 2009. Cara Praktis Pemrograman Java OOP/Swing/Database. Megatama. Bandung.

Anastasia Diana, Lilis Setiawati. 2011. Sistem Informasi Akuntansi, Perancangan, Prosedur dan Penerapan. Edisi 1. Yogyakarta: Andi Yogyakarta.

Andri Kristanto (2008) Perancangan Sistem Informasi dan Aplikasinya Gava Media, Yogyakarta.

Anhar. 2010. Panduan Menguasai PHP \& MySQL Secara Otodidak. Jakarta: Mediakita.

Arief M Rudianto. 2011. Pemrograman Web Dinamis menggunakan PHP dan MySQL. C.V ANDI OFFSET. Yogyakarta.

Hasibuan, Malayu S.P. 2011. MANAJEMEN: Dasar, Pengertian, dan Masalah. Jakarta: PT Aksara.

Jamaliyah. 2011. Sistem Informasi Akademik berbasis Client-Server. (Studi Kasus :Mts AlNizhamiyah Cileungsi). Fakultas Sains dan Teknologi, UIN Syarif hidayatulloh, Jakarta.

Miftah. Faridl. 2015. Fitur Dahsyat Sublime Text 3.Surabaya: Lug Stikom.

Puspitasari. 2011. Pemrograman Web Database dengan PHP \& MySQL. Jakarta: Skripta.

Roger S. Pressman, 2009. Rekayasa Perangkat Lunak Pendekatan Praktisi (BukuSatu). Yogyakarta: Andi.

Satzinger, Jhon W., Jackson, Robert B. dan Burd, Stephen D. 2012. System Analysis And Desig In A Changing World. Course Technology. USA.

Sommerville, Ian. 2011. Software Engineering (Rekayasa Perangkat Lunak). Jakarta: Erlangga.

Sugiarti, Yuni,S.T.M.Kom, 2013. Analisis dan Perancangan UML (Unified Modeling Languege), Graha Ilmu. Yogyakarta. 
Sukamto, R. A. dan M. Shalahuddin, 2013. Rekayasa Perangkat Lunak. Bandung: Informatika.

Sutabri, Tata. 2012. Analisis Sistem Informasi. Yogyakarta: Andi.

Widjajanto, Nugroho. 2008. Sistem Informasi Akuntansi. Jakarta. Erlangga, PT Gelora Aksara Pratama.

Rizky, Soetam. 2011. Konsep Dasar Rekayasa Perangkat Lunak. Jakarta: Prestasi Pustaka.

Raharjo,Budi. 2011. Belajar Otodidak Membuat Database Menggunakan MySQL. Bandung: Informatika.

Sutarman. 2012. Buku Pengantar Teknologi Informasi. Jakarta: Bumi Aksara.

Supono, dan Virdiandry Putratama. 2016. Pemograman Web Dengan Menggunakan PHP dan Framework Codeigniter. Yogyakarta: Deepublish (Grup Penerbitan CV Budi Utama).

Subhansyah, Nendy. 2011. Perancangan Sistem Akademik Sekolah Berbasis Teknologi Mobile Web ( Studi Kasus : SMA Muhammadiyah Tangerang ). Fakultas Sains dan Teknologi, Universitas Islam Negeri Syarif Hidayatullah Jakarta. 